\title{
Characteristics of Violin Tone
}

$\mathrm{T}^{\mathrm{H}}$ HE scientific explanation of certain qualities of violin tone is still an unsolved problem of great complexity. When a copy of an old Italian violin has not the tone qualities of the original, it is very difficult to find in what details the unfaithfulness of the copy lies. No new scientific technique remains long unapplied to the problem, and the most recent results were included in Major C. E. S. Phillips' discourse bearing the above title delivered at the Royal Institution on May 31.

Some X-ray work done in America has indicated the importance of using, for the backs of violins, material in which the speed of sound is the same in all directions. A violin was shown in which the back was replaced with copper, which somewhat muted the tone, and another with a bakelite back in which the tone was almost unaffected by the change. A 'cello with a body made entirely of copper had a pleasant, woody tone.

A small microphone used as a searching device shows that the whole violin is thrown into vibration when the strings are bowed. Although it has been supposed that the chief function of the sound post is to convey vibrations from the front to the back plate, it has been found that if this post is removed and external pressure brought to bear upon the top plate above where the sound post

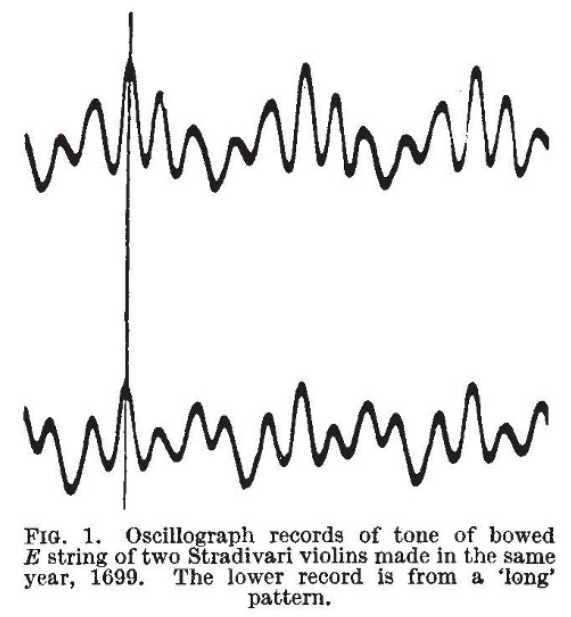

presses against it, the result is practically as good. Transillumination of two Stradivari violins shows that one with a higher arched front and back plate has been thinned more than one with a flatter front and back. The flatter top plate vibrates more easily under the pressure of the bridge than the one that is convex. The note heard on blowing across an ' $\mathrm{f}$ ' hole of any Stradivari violin has a frequency of 256 vibrations per second.
Scientific examination of the varnish question may prevent much more of the haphazard mixing of all manner of gums and lacs dissolved in oil in attempts to make varnishes with magical qualities. Molecular size is an important factor
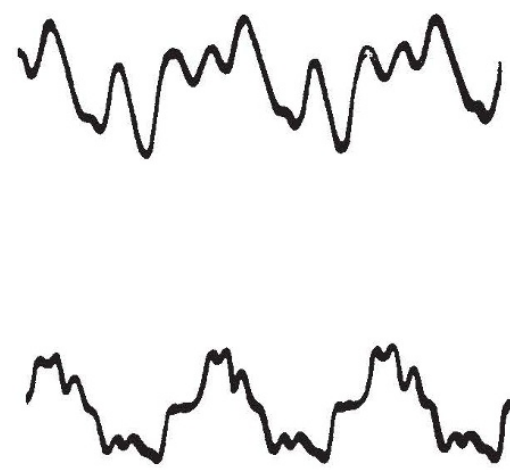

FIG. 2. Oscillograph records of tone of bowed $E$ string without (above) and with mute (below)

affecting the penetration of the body of a varnish through the closely packed semi-permeable membranous cells of wood. If a varnish made by dissolving celluloid in acetone be applied to pine, the solvent will rapidly soak into the wood, leaving the celluloid behind. The early Cremona varnish as used by Stradivari or Guarneri entered the wood. Penetration would be helped by using a solvent of low surface tension on carefully dried wood, with thorough cleaning and special treatment of the surface to reduce the contact angle. The manner of application may be specially favourable under the atmospheric conditions of Italy. Terpenes obtained from the distillation of larch would have been known to Stradivari, and may have helped penetration when used to 'wet' the clean wood in a warm dry air before the application of a thin coat of an amber varnish.

An unvarnished violin soon loses some of its sonorous qualities, which are regained on varnishing. The tone of a newly varnished instrument is dull until the varnish dries thoroughly and hardens. The inside of a violin is seldom coated, and is free to absorb moisture from the air. Such absorption, which may amount to $30 \mathrm{gm}$., tends to stiffen the plate and may affect the tone. It is possible that the improvement of clearness of tone of violins with age may be explained by supposing that the small molecules of the body of the varnish slowly build themselves into larger groups, assuming a more closely-packed structure with increased rigidity. Examination by means of ultra-violet light serves to distinguish between 
spirit and oil varnishes. Oil is present in all the 'Strads' so far examined by this means.

Since a violin is made up of seventy distinct parts, it would be surprising if the function of each were perfectly understood. For example, the tone of a violin without its back was found to preserve its main characteristic features. The result of the experimental removal of the sound post has been given already. The cuts and fretting of the bridge are not merely decorative. The rocking motion of the bridge in its own plane about the right foot as centre is important for fullness and quality of tone, which are but little affected when the effect of the rocking parallel to the strings is eliminated by reducing the feet to knife edges. Experiments in which the orientation of tiny steel rollers placed under the feet of the bridge was varied, were used to study this rocking motion of the bridge.

The latest attempt at the substitution of manufactured for grown fibres is in the use of artificial silk for horsehair of the violin bow. The viscose fibre retains the resin better than does the fine metal wire which is also in use for bows.

Microphone and cathode ray oscillograph have been used to obtain records of violin tone, and two examples are given in Figs. 1 and 2. During the discourse the famous 'Messie' Strad of 1760 was exhibited, and the intention of Mr. Arthur and Mr. Alfred Hill to present this unique instrument to the nation was announced. If, therefore, current scientific technique fails to solve all the problems of violin tone, future generations will have the problems handed to them in practical form.

\section{Obituary}

Prof. F. A. F. C. Went, For.Mem.R.S.

$\mathrm{O}^{2}$ N July 24 Prof. F. A. F. C. Went died at Wassenaar, near the Hague. He was born at Amsterdam on June 18, 1863, where he was also educated. He went to the University of Amsterdam in 1880, and worked under Hugo de Vries and also came in contact with Van 't Hoff and Van der Waals. After taking his doctorate in 1886 with a thesis entitled "De jongste toestanden der vacuolen" (The Youngest Stages of Vacuoles), Went spent some time in the laboratories of E. Strasburger (Bonn) and $\mathrm{Ph}$. Van Tieghem (Paris), and then he made his first visit to Java as a fellow of the Buitenzorg Foundation.

Deeply impressed both by Nature in the tropics and also by the work and organisation of Melchior Treub, Went shortly after his return received a call to the Java sugar industry. For five years (1891-96) he was director of the West Java Sugar Experimental Station at Kagok. In this capacity, working with the late Dr. J. H. Wakker, he did very important work on the diseases of sugar cane. The results of their studies were published in their well-known book "De ziekten van het Suikerriet op Java" (The Diseases of Sugar Cane in Java, 1898). He also studied photosynthesis in the sugar cane and the formation of sucrose and other carbohydrates. Went, therefore, may be regarded as one of the pioneers of experimental stations in the Dutch East Indies, which later achieved a great reputation. His experience in Java also considerably influenced his later work. $\mathrm{He}$ inspired his students by his conviction that development of the Dutch Colonies should be based on scientific knowledge and a thorough investigation of the natural resources of the tropics.

Went succeeded Prof. N. W. P. Rauwenhoff in 1896 as professor of botany in the State University of Utrecht. In the first decade, he still taught the entire field of botany, but later special chairs were provided for taxonomy and plant geography, phytopathology and genetics. At first there were only a few students in biology, but gradually he attracted a large number of students. This involved much heavy teaching for a devoted and conscientious teacher such as he was, and it left him little time for his own researches. His investigations were restricted to some work on enzymes and the curious family Podostemonaceae. He founded, however, a school of plant physiology, which is now well-known throughout the world.

In the beginning, Went directed his attention mainly to microbiological and mycological problems. Later on, however, systematic research was directed along two lines-one of them inspired by F. F. Blackman's theory of limiting factors and the temperature-reaction velocity ratio in vital phenomena, and the other on the nature of plant movements, where Pfeffer's conceptions were fundamentally attacked. A number of papers were issued in course of time on the influence of the temperature and limiting factors on the rate of germination, growth, respiration, carbon assimilation, protoplasmic streaming and also on the perception and reaction to 'stimuli' by plants.

The name of Went, however, is most closely connected with the problem of plant movements and especially with that of tropisms and growth. The nature of the problem was formulated in Blaauw's thesis (1909). The dependence of the phototropic response on the quantity of light (Blaauw), analogous relations in geotropism (Mrs. Rutten-Pekelharing) and finally the correlation between quantity of light and the phototropic curvatures (Arisz, 1914), suggested an exact quantitative analysis of tropisms. These investigations received a fresh impetus from Blaauw's 